\title{
STRATEGIES AND TECHNIQUES IN THE TRANSLATION OF MOVIE TITLES (AN ENGLISH-RUSSIAN COMPARATIVE CASE STUDY)
}

\author{
Radostina Iglikova ${ }^{3}$, Olga Usataya ${ }^{4}$
}

\begin{abstract}
The purpose of the present article is to popularize the findings and observations acquired from a corpus-based comparative case study of 200 Englishlanguage titles and their officially promoted Russian-language versions. The study observes and analyzes on a comparative basis the strategies and techniques employed in the translation of movie titles in the specific context of English-Russian translation. As a result of the nature of the study and its predominantly qualitative character, the results and observations are not intended to be representative or conclusive, but rather to provide a glance into the process of translation within a specific context, through the prism of a systematic classification of strategies and techniques. Due to volume limitations, the proposed article includes detailed analysis of only 10 titles excerpted from the entire corpus. These examples have been selected by the authors as representative to a large degree of the case study findings.
\end{abstract}

Key words: translation strategies, translation techniques, movie titles, English-Russian translation

\section{Introduction}

The title of any piece of textual or audio-visual material has the crucial effect of establishing the initial contact between the audience and the product. Whether the material is in printed or electronic/ digital form, whether it is a work of fiction or non-fiction, whether the heading is called a "title" (in the case of books and films, songs etc.) or a "headline" (as in the case of newspapers and website articles) - the importance of the first impression it creates is widely recognized by researchers (Iglikova, 2016; Iglikova, 2017a; Iglikova, 2017b; Iglikova, 2018; McGovern, 2002; Nielsen, 1998; Orendorff, 2014; Redish, 2012).

The title plays a significant role in the understanding of a film and the message it carries, which makes it serve as a key for decoding the presented information. In the context of globalization (see Giulianotti \& Robertson, 2006; Iglikova,

3. Assistant Prof. PhD at Shumen University, Department of English Studies, Shumen, Bulgaria, e-mail: r.iglikova@shu.bg

4. BA student at Shumen University, Department of English Studies, Shumen, Bulgaria, e-mail: olealiolik@mail.ru 
2013; Robertson \& White, 2007) and the hegemony of English-language movies the appropriate and successful translation of a movie's title is a must, as it affects a variety of aspects of film production, marketing and consumption. The badly or inappropriately translated title can affect the success of the movie and the size of the audience it reaches. The importance of the translator's work in rendering the title from the Source Language (SL) to the Target Language (TL) and the various difficulties this entails motivates the choice of the subject of the present study.

Film title translations are an interesting subject and have thus become a popular topic of discussion. As Counts (2005) claims:

As cinema evolved, so did the titles. After the implementation of sound, titles began to function as a transition. The translator must be able to write; he must be an original writer, sometimes it is not possible to translate the title verbatim - only the original title gives a clue how it should be translated, but the translator reveals the thoughts and ideas of the work by searching for equivalents in his native language.

Furthermore, the American graphic designer and Academy Award-winning filmmaker Saul Bass (Haskins, 1996, p. 12-13), best known for his design of motion-picture title sequences, film posters, and corporate logos claims:

My initial thoughts about what a title can do was to set mood and the prime underlying core of the film's story, to express the story in some metaphorical way. I saw the title as a way of conditioning the audience, so that when the film actually began, viewers would already have an emotional resonance with it.

Thus, creating a title is similar to making a poster - you concentrate the event in one phrase, produce one metaphor, a story to be told, or a character to be entered. Titles are often more innovative than the film itself and they can give the viewer considerable emotional satisfaction. The titles have a unique tone setting function, providing a mood and foreshadowing the action itself.

\section{Theoretical background of the case study}

\subsection{Research on the roles and functions of titles}

Regarding research into title translation, Nord (1995, p. 261-284) distinguishes six functions of titles that are to be taken into consideration in the process of translation. They can be grouped into two sets: essential and optional functions. The essential functions comprise the following types of function: distinctive (each title should be different from other titles which belong to the same corpus and culture), metatextual (each title should obey the genre conventions of the 
culture it pertains to), and phatic (each title must engage its culture-specific audience and, if required, should be remembered for some time). Among the optional functions we find the additional ones: referential (the information which is conveyed by means of the title must be easily understood by the addressees by resorting to their culture-specific world-knowledge), expressive (if there are any emotions or evaluations involved in the original title, they should be carried over to the target text), and appellative (any appellative intention must take into consideration the audience's susceptibility and expectations). Newmark (1988a, p. 57) also sheds some light on the functions and classification of titles, although this scholar pays considerable attention to the titles of literary works. According to Newmark, titles can be either descriptive (if they express the topic of the text) or allusive (if they relate referentially or figuratively to the topic of the text).

\subsection{Research on translation as a process. Translation strategies and techniques}

Translation involves the retextualization or recodification from a source text to a target text (Fernandez, Sacristan \& Olivera, 2005, p. 61-81). As Baicchi (2003, p. 319-341) observes, "the translator shapes his own representation of the meaning of the text". Since translation takes into account the specific communicative circumstances of both texts, Reiss, Vermeer, Nord and Dudenhoefer (2014) focus on the purpose of translation, which guides the translation techniques and methods that are to be used in order to render a functionally adequate product. Moreover, any text will be regarded as a translation if it is accepted as such within a given cultural system (or polysystem) at a given point in time leaving aside its quality and faithfulness to the original (Toury, 1995, p. 70-73).

Newmark's (1988b) discussion of the difference between translation methods and translation procedures equates the first with global translation strategies and the second with local translation strategies (i.e., "techniques", according to Jaaskelainen, 1993, p. 116). He writes that, "(w)hile translation methods relate to whole texts, translation procedures are used for sentences and the smaller units of language" (1988b, p. 81).

According to Newmark, "only semantic and communicative translation fulfill the two main aims of translation, which are first, accuracy, and second, economy. [...] In general, a semantic translation is written at the author's linguistic level, a communicative at the readership's. Semantic translation is used for 'expressive' texts, communicative for 'informative' and 'vocative' texts" (Newmark, 1988a, p. 47; Peneva, 2018). In addition, according to Newmark there exists a continuum between "semantic" and "communicative" translation - any translation can be "more, or less semantic - more, or less, communicative - even a particular section or sentence can be treated more communicatively or less semantically" (1991, p. 10-12). 
Jaaskelainen (1993, p. 116) shows the difference between two strategies: global strategies (i.e., "the translator's general principles and preferred modes of action") and local strategies (i.e., "specific activities in relation to the translator's problem-solving and decision-making"). From his point of view, global strategies include literal and free translation, as the translator should think about the goal of the translation and the effect of the target text on readers. The chosen global strategy will influence the translation process. Since local strategies are classified by comparison with the source text, and they exist together with specific techniques which affect the translation result and the micro-units of the text (Molina \& Albir, 2002, p. 509), local strategies are in fact translation techniques.

Among local translation strategies, Chesterman (1997, p. 87-116) distinguishes between comprehension strategies (for understanding and analyzing the source text) and production strategies (for the production of the target text). From a linguistic perspective, he divides production strategies into mainly syntactic/grammatical, mainly semantic and mainly pragmatic strategies, with each category containing ten techniques. Syntactic strategies involve purely syntactic changes, manipulate form, and include such techniques as calque, transposition, and sentence structure change. Semantic strategies mainly pertain to changes concerning lexical semantics. They manipulate meaning and contain techniques such as synonymy, emphasis change, and paraphrase. Pragmatic strategies have to do with the selection of information in the target text, and often involve syntactic and/or semantic changes as well. Pragmatic strategies include cultural filtering, explicitness change, information change, etc. Some of these techniques are obligatory during translation in a given language pair, while most are optional.

For the purposes of the present study, the term translation strategy will be taken to refer to one of the two methods of translation or global strategies (see Jaaskelainen, 1993, p. 116; Newmark, 1988a) - i.e. the overall intention of the translator to either stay as close to the original as possible in every sense of the word, or, on the contrary, to attempt to make the translation as close to the TL and its specificities and requirements as possible. Thus, the existing continuum between SL-oriented semantic and TL-oriented communicative translation strategies will be explored. On the other hand, the so-called local strategies (see Chesterman, 1997, p. 87-116) will be referred to as translation techniques, subsuming the actual transformations and procedures utilized by the translator in the process of translation.

\section{Case study}

Due to objective limitations concerning the volume of the present article, it offers a detailed analysis of 10 of the 200 titles comprising the corpus. For the 
purposes of the present study, the titles analyzed in detail here will be classified in terms of the global strategy of translation they most closely follow and will thus be grouped in two separate groups - SL-oriented and TL-oriented.

\subsection{SL-oriented - semantic translation}

\section{Example 1: The Great Wall - Великая стена (2016)}

\section{Strategy: SL-oriented (semantic translation)}

Techniques: syntactic transformation - phrase structure change

This title refers to one of the most famous and largest monuments of architecture - the Great Wall of China. It has an established Russian equivalent - "Великая Китайская стена" - which allows the translator to remain very close to the original. The original title employs a reduced version of the name, omitting "of China" and so does the translation by omitting "Китайская". The only necessary and inevitable transformation involves a syntactic change in the phrase due to the discrepancy in expressing definiteness between Russian and English. Therefore, the definite article "the" and the grammatical definiteness it entails are omitted in the Russian variant.

\section{Example 2: City of Ghosts - Город призраков (2002)}

Strategy: SL-oriented (semantic translation)

Techniques: syntactic transformation - calquing; phrase structure change

The title contains an allusion to the set phrase "ghost town", defined as "an abandoned village, town, or city, usually one that contains substantial visible remains" ("Ghost town", n.d.). This is a well-established notion among the English-speaking world and the United States in particular - illustrated by the existence of a number of literary works and movies carrying that title ("Ghost town (disambiguation)", n.d.). The title itself employs a paraphrased version of the set phrase, substituting "town" for "city" and employing syntactic change by expressing the attributive function of "ghost" in relation to city/ town not by means of a word order (as in the original set phrase) but by using the preposition "of". In the Russian translated version this distinction between "town" and "city" is not felt - "город" is the lexeme denoting urban rather than rural settlement, which does not have specific size connotations like the English town versus city does. Thus, the Russian variant is closer to the English set phrase "ghost town" and preserves the semantic connotations of the expression, thereby employing the technique of calquing. It does, however, employ the inevitable syntactic transformations as required by the TL grammatical requirements. For this purpose the attributive function is expressed not by means of a word order or preposition (as is the case in English) but instead by means of the use of the 
plural Genitive case form of the lexeme “призрак” ("ghost”) - „призраков” ("of the ghosts"/ "ghosts"”.

\section{Example 3: Chocolat - Шоколад (2000)}

Strategy: SL-oriented (semantic translation)

\section{Techniques: semantic transformation}

Although it is an English-language production, the title of this movie is in fact a French word, as is demonstrated by its spelling - although they are extremely similar, the English lexeme is spelled "chocolate" instead of "chocolat". The different spelling, however, has specific connotations and a specific pronunciation - thus adding to the special, romantic and exotic nature of the notion. The Russian variant, however, does not have a mechanism for graphically acknowledging the French overtones in the title and reduces it semantically to the neutral Russian lexeme “шоколад". It could be argued, however, that the term “шоколад” itself has these connotations in Russian which imbue it with similar overtones of something special, romantic and perhaps forbidden, meaning that the Russian title is in fact quite faithful to the original.

\section{Example 4: Kingdom of Heaven - Царство небесное (2005)}

Strategy: SL-oriented (semantic translation)

Techniques: syntactic transformation - phrase structure change; lexico semantic adaptation; pragmatic transformation - information change;

The original title is a paraphrased version of the "Heavenly Kingdom". "Officially, The Heavenly Kingdom of Great Peace was an oppositional state in China from 1851 to 1864, supporting the overthrow of the Qing dynasty by Hong Xiuquan and his followers" ("Taiping Heavenly Kingdom", n.d.). The semantic and functional equivalent of The Heavenly Kingdom of Great Peace in Russian is "Тайпинское Небесное Царство” (“Taipinskoe Nebesnoe Tsarstvo", n.d.). In the Russian version of the title, however, is employed an inverted and reduced version - "Царство Небесное" (Tsarstvie Bozhie"/ “Царствие Божие”, n.d.), which has Biblical connotations („,область на небесах, где души праведников пребывают в раю"/ "а specific area in the heavens where the souls of virtuous people abide in heaven". The "Kingdom of God" and its equivalent form "Kingdom of Heaven" in the Gospel of Matthew is one of the key elements of the teachings of Jesus in the New Testament ("Kingship and kingdom of God", n.d.). This way the translated version substitutes one set of culturally and historically specific connotations for another and redirects allusions made by the original title from Chinese to Biblical (the Old and/or the New Testament) objects. In this sense it might be argued that the translated variant is not a case of literal translation, since although the lexical items are extremely similar in their form, the connotations and meanings they involve are quite different and 
remote from one another. This makes it plausible for the title to be treated as a case of adaptation.

\section{Example 5: Twilight - Сумерки (2008)}

Strategy: SL-oriented (semantic translation)

Techniques: syntactic transformation

Since the title consists of a single noun which has a direct correspondence in Russian, the translator has decided to apply literal translation by rendering the lexeme "twilight" via "сумерки". The only difference between the original and the Russian version is due to the grammatical specificities of the Russian language where the lexеmе „сумерки” is a Pluralia tantum noun and therefore has no Singular form corresponding to the Singular English "twilight".

\subsection{TL-oriented - communicative translation.}

\section{Example 6: Seven Sisters - Тайна 7 сестер (2017)}

Strategy: TL-oriented (communicative translation)

Techniques: syntactic transformation - phrase structure change, lexical addition; pragmatic transformation - information change;

The original title quite obscurely uses enumeration ("Seven Sisters"), thus providing potential viewers with nothing but thematic information. Any rhematic information concerning the theme is left implicit in the original and is expected to be revealed by watching the movie - the seven sisters being the characters and the plot of the movie supplying the events taking place. The Russian variant employs lexical addition - "тайна" (,secret”) and this leads to additional syntactic transformations related to the TL grammatical requirements, such as the use of the Genitive case to express attributive relations between "seven sisters" and "secret". This way the title becomes "The secret [of the] Seven Sisters" or "[The] Seven Sisters' Secret", which constitutes the pragmatic transformation of information change - adding information which was not present in the original.

\section{Example 7: Spider-Man - 3 - Человек-паук-3: Враг в отражении (2007)}

Strategy: TL-oriented (communicative translation)

Techniques: syntactic transformation - calque, sentence structure change clause addition, cohesion change; semantic transformation - emphasis change; pragmatic transformation - information change;

The original title of this film is quite short and contains the numeral " 3 " spelled via a digit, which identifies the movie clearly as part of a series of movies, thus signaling and emphasizing relations of intertextuality. The noun phrase "spider- 
man" is a well-established one, referring to a specific cartoon character who is recognizable around the globe. This requires the translator to use loan translation by employing the calque "человек-паук". This, however, is the only part of the title where the TL variant is close to the original. The rest of the Russian variant places emphasis on the added description of the movie itself rather than on its being part of a series. The added clause is not present in the original title and is a case of information change - the entire part "враг в отражении" "“[the] enemy in the reflection") represents information which is not part of the original title at all. It is, perhaps, added based on a combination of two elements. On the one hand, the addition can be the result of a quite literal description of the movie poster images, where the main character is represented as looking at his own reflection - in this case, the Russian variant is constructed via putting into words the visual information in the poster. On the other hand, the plot line can serve as inspiration for this addition, since in this movie Spider-man faces himself as his own enemy (or, as the movie's slogan states, "the greatest battle lies within").

\section{Example 8: Вabe - Бэйб: Четвероногий малыш (1995)}

Strategy: TL-oriented (communicative translation)

Techniques: syntactic transformation - transcription, sentence structure change; pragmatic transformation - information change;

The original title contains a single lexeme referring to the name of the main character, "Babe", which is transcribed as „Бэйб”. In addition to this part, which is identical with the original title, the Russian variant employs syntactic transformation as a result of which the syntactic structure of the title is changed. The Russian variant thus contains a second part, „четвероногий малыш"(literally, "[the] four-legged baby") which serves as an attribute to the first part, as the loan word „Бэйб” in Russian lacks the direct connotations of „baby" or "small one" which it has in English. By means of adding the second clause, the Russian version compensates for this discrepancy between the SL and TL and includes the information that the main character, Babe, is a four-legged baby (i.e. a young/small animal). Since the original title does not state explicitly that Babe is an animal, the addition constitutes a pragmatic transformation information change.

\section{Example 9: Bad Moms - Очень плохие мамочки (2016)}

Strategy: TL-oriented (communicative translation)

Techniques: syntactic transformation - unit shift; phrase structure change; pragmatic transformation - information change;

The original title of the movie contains a noun phrase which is neutral - "bad moms", whereas the TL variant employs unit shift to give additional emphasis to both of the original elements. This way "bad" becomes „очень плохие" 
("very bad") and “moms” becomes the diminutive „мамочки” (“mommies” or "mamas"), which constitutes a change in the phrase structure. These marked TL variants are in fact a case of information change, as they express meanings which are not present in the SL title, such as the gradation expressed by adding „очень" or "very" and the diminutive aspect of the lexeme „мамочки" that is not present in the neutral English "moms".

\section{Example 10: Road to Perdition - Проклятый путь (2002)}

Strategy: TL-oriented (communicative translation)

Techniques: syntactic transformation - transposition, phrase structure change; semantic transformation - emphasis change; pragmatic transformation explicitness change;

The SL version contains a play on words based on the dual meaning of the noun "perdition" in the context of the movie. "Perdition", on the one hand, is a common noun synonymous with damnation and on the other - a toponym, referring to a fictional town on the shore of Lake Michigan ("Road to Perdition", n.d.) where part of the action in the movie takes place. This way the title in English can be rendered in two ways: a road/pathway to being lost; the actual road to the place called Perdition. In Russian this ambiguity cannot be retained due to the lack of an equivalent lexeme expressing both notions, so the translator faces the choice between retaining either one or the other. In this case, the Russian variant employs syntactic changes due to which the notion of a "road to somewhere (a place/state)" is substituted for a "specific kind/type of road" - thus the noun "perdition" (literally, ,проклятие") is transposed and shifted into an adjective - „проклятый” (literally, "damned”) which results in a phrase structure change. Transformation also occurs on the semantic level, where emphasis is shifted from the rhematic element "Perdition" to the noun "road" („путь"). As the translator chooses to retain one of the meanings of the noun "Perdition" and renders it as „проклятый [путь]”, a pragmatic transformation can be observed as one explicit meaning in the original is omitted. These transformations result in the version „Проклятый путь” or “Damned road”.

\section{Conclusion}

In the current reality of global communication, translation plays a key role in establishing the exchange of information between languages. For this purpose and in order to successfully convey meanings from one language to another, translators need particular skills, which are subsumed under what we refer to as translation strategies and techniques.

In this study, translation in general, translational problems and mainly translation strategies and techniques were described, and different theories of 
translation strategies, methods, techniques and procedures were mentioned. It was shown that different theorists suggest various definitions according to their different perspectives. However, the definition offered by each author or theorist represents his/her own point of view and their views differ from each other. Most theorists agree that strategies and techniques are used by translators when they encounter a problem and literal translation does not work.

The results from the study show the following preferences:

- In terms of Global Translation Strategies, there is a clear preference for employing SL-oriented strategy and semantic translation - out of the 200 randomly selected titles comprised in the corpus, 118 are translated by applying SL-oriented strategy and 82 - TL-oriented strategy;

- In terms of Local Translation Strategies, i.e. translation techniques, there is a consistent preference for employing specific sets of techniques depending on the global strategy employed; in other words, SL-oriented translations employ one set of techniques and TL-oriented ones - another;

- SL-oriented, semantic translations are usually realized by means of the use of syntactic transformations such as literal translation, calquing, transcription or transliteration; in case of grammatical differences between the two languages, there are usually phrase structure changes - often the use of case forms in Russian instead of the use of prepositions or word order in English;

- TL-oriented, communicative translations involve a much more complex set of transformations, usually including techniques of all three levels syntactic, semantic and pragmatic; most often syntactic transformations involve phrase- and clause-structure changes, semantic transformations involve predominantly paraphrase and more rarely synonymy, while pragmatic transformations most commonly involve information change and more rarely - explicitness change.

As the present study does not claim to be statistically representative in its findings, it intends to serve as an additional piece of the puzzle known as translation studies and research on the practice of translation. It can also be useful for student translators of English into Russian (and not only) who might find it useful and interesting to study and analyze in detail the strategies and techniques professional translators employ.

\section{References:}

Baicchi, A. (2003). Relational complexity of titles and texts: A semiotic taxonomy. In L. M. Barberesi (Ed.), Complexity in language and text (pp. 319-341). Pisa: Edizioni PLUS Universita di Pisa. 
Bell, A. (1984). Language style as audience design. Language in Society, 13(2), 145-204.

Bell, A. (1994). The language of news media. Oxford: Blackwell Publishers, Ltd.

Chesterman, A. (1997). Memes of translation: The spread of ideas in translation theory. Amsterdam \& Philadelphia: John Benjamins.

Counts, J. (2005). Just the beginning: The art of film titles. Retrieved from http://www. twenty4.co.uk/on-line/issue001/project01/proj01index.htm.

Fernandez, S. E., Sacristan, V. M., \& Olivera, F. P.A. (2005). Translations we live by: the impact of metaphor translation on target systems. In Olivera, F. P. (Ed.), Lengua y sociedad: Investigaciones recientes en linguistica aplicada (pp. 61-81). Valladolid, Spain: Servicio de Publicaciones.

Giulianotti, R., \& Robertson, R. (2006). Glocalization, globalization and migration: the case of Scottish football supporters in North America. International Sociology, 21(2), 171-198.

Haskins, P. (1996). Saul, can you make me a title? Interview with Saul Bass. Film Quarterly, 50(1), 12-13.

Iglikova, R. (2013). Nyakoi problemi na sapostavitelnite izsledvaniya varhu efektivnostta na tekstove ot elektronniya diskurs/ Игликова, Р. Някои проблеми на съпоставителните изследвания върху ефективността на текстове от електронния дискурс. In S. Nedelcheva \& D. Cheshmedzhieva-Stoycheva (Eds.), Dynamics, interdisciplinarity, diversity (pp. 70-74). Shumen: Konstantin Preslavsky University Press.

Iglikova, R. (2016). What's your number? - numeral preference in viral headlines from 3 websites. Lyuboslovie, 16, 203-211.

Iglikova, R. (2017a). Efficiency and headline patterns on the Cosmopolitan United States website. KNOWLEDGE - International Journal, 19.3, 1295-1300.

Iglikova, R. (2017b). Headline patterns in viral web content-English-Bulgarian comparative case study. In Todorova et al. (Eds.), Series in Linguistics, Culture and FLT, 2, 71-84.

Iglikova, R. (2018). Efficiency and headline patterns on the Cosmopolitan Bulgaria website. KNOWLEDGE - International Journal, 23.5, 1473-1478.

Jaaskelainen, R. (1993). Investigating translation strategies. In S. Tirkkonen-Condit \& J. Laffling (Eds.), Recent trends in empirical translation research (pp. 99-120). Joensuu: University of Joensuu Publications in Humanities.

Jaaskelainen, R. (1999). Tapping the process: An explorative study of cognitive and effective factors involved in translating. Joensuu: University of Joensuu Publications in Humanities.

McGovern, G., Norton, R., \& O’Dowd, C. (2002). The web content style guide. An essential reference for online writers, editors and managers. London: Financial Times Prentice Hall.

Molina, L., \& Albir, H. A. (2002). Translation techniques revisited: a dynamic and functionalist approach. Meta, 47(4), 498-512.

Newmark, P. (1988a). A textbook of translation. Hertfordshire: Prentice Hall.

Newmark, P. (1988b). Approaches to translation. Hertfordshire: Prentice Hall.

Newmark, P. (1991). About translation: Multilingual matters. Clevedon, Philadelphia, Adelaide: Multilingual Matters Ltd. 
Nielsen, J. (1998). Microcontent: how to write headlines, page titles, and subject lines. Retrieved from http:/www.nngroup.com/articles/microcontent-how-to-write-headlinespage-titles-and-subject-lines/

Nord, C. (1995). Text-functions in translation: titles and headings as a case in point. Target, 7(2), 261-284.

Orendorff, A. (2014). The ultimate copy checklist: 51 questions to optimize every element of your online copy. Retrieved from http:/www.copyblogger.com/optimize-online-copy/

Peneva, D. (2018). A methodological approach in the comparative analysis of speech act patterns. Lyuboslovie, 18, 252-266.

Redish, J. (2012). Letting go of the words. USA: Elsevier.

Reiss, K., Vermeer, H. J., Nord, C., \& Dudenhoefer, M. (2014). Towards a general theory of translational action: Skopos theory explained. London \& New York: Routledge.

Robertson, R., \& White, K. E. (2007). What is globalization? In The Blackwell companion to globalization (pp. 62-63). Oxford: Blackwell Publishing Ltd.

Taipinskoe Nebesnoe Tsarstvo. Тайпинское Небесное Царство. (2018, октябрь 7). Википедия, свободная энциклопедия. Retrieved 11:19, августа 10, 2019 from https://ru.wikipedia.org/?oldid=95486647.

Toury, G. (1995). Descriptive translation studies and beyond. Amsterdam/ Philadelphia: John Benjamins.

Tsarstvie Bozhie. Царствие Божие. (2019, июль 5). Википедия, свободная энциклопедия. Retrieved 11:20, августа 10, 2019 from https://ru.wikipedia.org/?oldid=100837182.

Wikipedia contributors. (2019, August 10). Taiping Heavenly Kingdom. In Wikipedia, The Free Encyclopedia. Retrieved 11:18, August 10, 2019, from https://en.wikipedia.org/w/ index.php?title=Taiping_Heavenly_Kingdom\&oldid $=910150825$

Wikipedia contributors. (2019, July 27). Road to Perdition. In Wikipedia, The Free Encyclopedia. Retrieved 11:21, August 10, 2019, from https://en.wikipedia.org/w/index. php?title=Road_to_Perdition\&oldid=908050619

Wikipedia contributors. (2019, July 31). Ghost town. In Wikipedia, The Free Encyclopedia. Retrieved 11:16, August 10,2019, from https://en.wikipedia.org/w/index.php?title=Ghost town\&oldid $=908772503$

Wikipedia contributors. (2019, July 4). Kingship and kingdom of God. In Wikipedia, The Free Encyclopedia. Retrieved 11:20, August 10, 2019, from https://en.wikipedia.org/w/ index.php?title=Kingship_and_kingdom_of_God\&oldid=904760397

Wikipedia contributors. (2019, June 25). Ghost town (disambiguation). In Wikipedia, The Free Encyclopedia. Retrieved 11:18, August 10, 2019, from https://en.wikipedia.org/w/ index.php?title=Ghost_town_(disambiguation)\&oldid=903419569 